University of Nebraska - Lincoln

DigitalCommons@University of Nebraska - Lincoln

Faculty Publications of the Center on Children, Families, and the Law

Children, Families, and the Law, Center on

2005

\title{
Pulpits and Platforms: The Role of the Church in Determining Protest among Black Americans
}

\author{
Scott T. Fitzgerald \\ University of North Carolina at Charlotte \\ Ryan Spohn \\ University of Nebraska-Lincoln, rspohn@unomaha.edu
}

Follow this and additional works at: https://digitalcommons.unl.edu/ccfffacpub

Part of the Family Law Commons

Fitzgerald, Scott T. and Spohn, Ryan, "Pulpits and Platforms: The Role of the Church in Determining Protest among Black Americans" (2005). Faculty Publications of the Center on Children, Families, and the Law. 5.

https://digitalcommons.unl.edu/ccffacpub/5

This Article is brought to you for free and open access by the Children, Families, and the Law, Center on at DigitalCommons@University of Nebraska - Lincoln. It has been accepted for inclusion in Faculty Publications of the Center on Children, Families, and the Law by an authorized administrator of DigitalCommons@University of Nebraska - Lincoln. 


\title{
Pulpits and Platforms: The Role of the Church in Determining Protest among Black Americans
}

\author{
Scott T. Fitzgerald, University of North Carolina at Charlotte \\ Ryan E. Spohn, Kansas State University
}

\begin{abstract}
This article further specifies the relationship between church-based resources, group identification and political activism among black Americans. Previous research indicates that political communication within churches and activism within the church serve to motivate political participation. Our research suggests that, net of relevant controls, activism within the church does not significantly increase protest politics. A key determinant of protest participation is attending a church that exhibits a politicized church culture, and this effect is contingent upon educational attainment and membership in secular organizations. Hence, the church serves as a crucial context for the dissemination of political messages and exposure to opportunities for protest only for those black Americans with relatively low educational achievement and organizational involvement. Group identification has no effect on protest participation.
\end{abstract}

From the black Civil Rights movement to Poland's Solidarity movement, from the Nicaraguan revolution of 1979 to the South African anti-Apartheid movement, from Gandhi's movement for Indian independence to the U.S. Central America peace movements of the 1980s, people and organizations of faith have contributed indispensable resources to mobilization of disruptive political activism.

- Smith 1996

Churches, congregations and other religious organizations provide an array of sectarian and secular goods to participants. Through these organizations individuals can receive spiritual guidance, fellowship and sanctuary while building friendships and social networks. In modern western democracies, political views are expressed by the public through both institutional and non-institutional means. Institutional activities (voting, lobbying, petitioning) and non-institutional activities (protest) represent calculated attempts by individuals and groups to communicate their goals and affect change. If that is the case, why do some individuals engage in protest behavior while others do not? What role do religious institutions and beliefs play in producing protest?

Research has shown that the decision to participate in protest behavior, or social movement activity more generally, is influenced by pre-existing organizational ties (McAdam 1986; Morris 1981) and contact with participants (Snow, Zurcher and Eckland-Olson 1980). Being asked to participate in an activity, such as political protest, is a crucial step in the process of engaging in protest behavior (McCarthy and Zald 2002). Some churches and other religious organizations engage in political activity as an organization (Beyerlein and Chaves 2003; Chaves 2004; Lincoln and Mamiya 1990) or encourage political action by members

We would like to thank Kevin Leicht and Ed Collom for comments on an earlier version of this article that was presented at the 2002 American Sociological Association Meetings, August 15-17, in Chicago, IL. We also thank the Social Forces editor and anonymous reviewers. Direct correspondence to Scott Fitzgerald, Department of Sociology and Anthropology, University of North Carolina at Charlotte, 9201 University City Boulevard, Charlotte, NC 28223-0001. E-mail: sfitzger@email.uncc.edu. 


\section{6・Social Forces Volume 84, Number 2・December 2005}

(Brown and Brown 2003; Lee 2003; Williams 2004). Thus, in addition to being a place of worship, churches provide the physical and social space that may lead to political action and protest behavior (McVeigh and Sikkink 2001).

The scope of demographic, social and technological changes associated with industrial revolution led some to predict the demise of religion as a significant social institution. Modernization theorists posited that the forces of industrialization would rip asunder the social fabric and traditional values that cultivated religious outlooks; appeals to supernatural forces would be replaced by scientific, materialist explanations of the physical and social world. The unique founding conditions and rapid industrialization of the United States appeared to be an ideal vantage point from which to watch this transformation unfold. Yet, as political scientist Kenneth Wald quips, “...American religion, like Mark Twain, has obstinately refused to comply with reports of its demise." (Wald 2003:07)

By most measures, the United States remains a deeply religious nation (Gallup and Castelli 1989; Wald 2003). The import of organized religion for Americans as a whole is particularly pronounced for African Americans who have higher levels of religious belief and church participation than other Americans (Fowler, Hertzke and Olson 1999). From the years of slavery through the Jim Crow era, the black church played a crucial role by providing periodic sanctuary to its members forced to live in an oppressive and hostile society. The church was a social institution that provided a venue for the development of basic skills (e.g. reading and writing) and cultivation of a world-view that provided comfort and hope in the face of tremendous hardship (Baer and Singer 1992; Harris 1999; Lincoln and Mayima 1990).

Despite the fact that some formal church leaders were slow to support Civil Rights activism (Payne 1995; Robnett 1997), the black church facilitated activism in at least two important ways. First, as evidenced by the speeches of the Rev. Martin Luther King, Jr., religious themes and biblical references were central to the framing of the Civil Rights movement (McAdam 1996). Second, the churches played a key role in the mobilization of blacks by providing the organizational and institutional resources necessary for boycotts, sitins and other protest activities (McAdam 1982; Morris 1981, 1984). Churches are also a mechanism for pooling and organizing resources. Recent research has confirmed that churches continue to play an important role in cultivating and directing political action among African Americans (Brown and Brown 2003). In this article we set out to further specify the relationship between church involvement and political action by assessing the relative importance of demographic, organizational and ideological factors. We seek to answer three related questions: First, net of relevant controls, do church attendance, church activism and/or politicized church cultures ${ }^{1}$ affect political protest behavior? Second, are these effects mediated by organizational resources involvement and/or "group identification?" Third, are these effects contingent upon other factors such as educational attainment?

This article unfolds in three stages. First, we draw from previous research on social movements, political behavior and religion to develop hypotheses for predicting political protest behavior. Second, using data drawn from a national sample of black Americans, we test these hypotheses by modeling the relationship between political protest behavior and our theoretical variables. Third, we discuss the implications of these findings and offer suggestions for further research on this topic.

\section{Who Protests?}

A central theoretical and empirical concern for social movement researchers and theorists is explaining protest participation. Why do some individuals engage in protest behavior while others do not? Various "grievance theories" of social movements argued that variation in 
Pulpits, Platforms and Protest among Black Americans • 1017

individuals' protest participation can be explained in terms of socioeconomic status. Sudden increases in individual grievances generally resulting from structural strains are the key determinant of the development and/or growth of protest activity (Geschwender 1964; Gusfield 1970; Kornhauser 1959; Turner and Killian 1957). To the extent that they were politically active, higher-status individuals were predicted to dominate conventional political activities, whereas poor, lower-status individuals or people facing suddenly harsh conditions were expected to dominate protest politics. Subsequent research challenged that while grievances may be a necessary condition to collective behavior, they are not a sufficient condition (Jenkins 1983; McCarthy and Zald 1977).

As the empirical accuracy of grievance theories came into question and the form of social movements as well as the characteristics of their members began to change in the 1960s, new theories of political participation emerged focusing on resources and organizations. Resource mobilization theorists (RMT) argue that grievances are not a central concept, but play (at most) a secondary role in the formation of social movements (Jenkins 1983; McAdam, McCarthy and Zald 1996; McAdam and Zald 2002; McCarthy and Zald 1977). Instead, the development of movements primarily depends on the availability of resources, group organization and opportunities for collective action (Cress and Snow 1996). In fact, resource mobilization theory inverts the logic of grievance theories, suggesting that movements are more likely to emerge when the status of aggrieved groups improves because these additional resources will improve the likelihood of group success (Jenkins 1983; McAdam and Zald 2002; McCarthy and Zald 1977).

Explanations of the involvement of individuals in protest politics highlight the import of organizational ties and affiliations (McAdam 1982; Morris 1981). In an early review of resource mobilization theory, Jenkins suggests, "the mobilization potential of a group is largely determined by the degree of preexisting group organization." (1983:538) As a result, movement leaders focus recruitment efforts on individuals who are active in organizations that support social change and individuals who are structurally available for participation. McCarthy and Zald (1977) suggest that the aggregation of resources is a necessary task for social movements, and that this search for resources requires at least a minimum amount of organization. Consequently, rather than seeking out aggrieved individuals to fill their ranks, movements are interested in members from higher social classes who are highly educated, have a history of political involvement, and can provide resources such as labor and money (Jenkins 1983; McCarthy and Zald 1977). Thus, just as studies of electoral behavior from political scientists predict that higher status individuals are more likely to undertake conventional political activities (see Verba and Nie 1972, for example), resource mobilization theorists predict that higher status individuals are pursued as members of social movement organizations (cf. Piven and Cloward 1977).

Participation in protest activity is also likely to be affected by biographical availability (McAdam 1986; McCarthy and Zald 1977; Wiltfang and McAdam 1991). Biographical availability refers to "the absence of personal constraints that might increase the costs and risks of movement participation, such as full-time employment, marriage and family responsibilities." (McAdam 1986:70). Because of their age and limited labor market participation, students are often considered to be ideal protestors because they are more likely to have time and energy to participate in protest activities (Lipset and Wolin 1965; McCarthy and Zald 1977; McPhail 1971; McPhail and Miller 1973; Morris 1981; Orum 1972; Snow et al. 1980). However, this phenomenon may simply be the result of historical contingencies and/or cohort effects. Since the 1970s, protesting has become less common for people under the age of 30 while it has increased among middle-aged and older people (Putnam 2000; Verba, Schlozman, and Brady 1995).

Other studies have sought to broaden the scope of analysis beyond questions of structural location and resources by examining the role of culture in mobilization and protest 


\section{8 • Social Forces Volume 84, Number 2・December 2005}

(Fantasia 1988; Goodwin and Jasper 2003; Harris 1999; Johnston and Klandermans 1995; Melucci 1989; Morris and Mueller 1992; Payne 1995; Poletta 1997; Robnett 1997; Williams 2002, 2004). These studies point to the importance of "nonmaterial cultural assets (e.g., identities, symbols and networks of relationships)" in producing protest and movement activity (Williams 2004:132). One stream of cultural analysis focuses on the emergence and role of movement cultures during times of broader social tension and change (Johnston 1991; Morris 1984; Swidler 1986, 1995; Taylor 1989; Taylor and Whittier 1995). Fantasia's study of working-class organization documents how "cultures of solidarity," oppositional "tactical activities, organizational forms and institutional arrangements," emerge from within the broader culture during times of crisis (1988:20). Whether conceptualized as "abeyance structures" (Taylor 1989), "submerged networks" (Melucci 1989; Mueller 1994), or "oppositional subcultures" (Johnston 1991), this research has illuminated the culture's mediating role between opportunities and mobilization.

\section{Religion as an Impetus for Protest}

The relationship between religion and political behavior is complex and at times contradictory (Billings and Scott 1994; Fowler et al. 1999; Hunt and Hunt 1997; Marx 1967; Smith 1996; Wald 2003). On the one hand, religious institutions and beliefs can suppress oppositional activities such as political protest by encouraging conformity and propagation of the status quo. For example, a pooled-sample analysis of National Opinion Research Center's (NORC) General Social Survey data for the 1970s through the mid-1980s found that religiosity (measured as strength of religious affiliation and frequency of church attendance) was negatively related to protest for both black and white Americans (Secret, Johnson and Forrest 1990). Analyzing 1970s data from the United States, another researcher found that church attendance had a negative effect on protest behavior (Anderson 1996). On the other hand, as illustrated by the opening quotation, religious institutions and beliefs can provide the organizational and cultural tools necessary to challenge prevailing systems (Harris 1999; Smith 1996; Williams 2002). Survey data from the United States has revealed that public religiosity (measured as frequency of church attendance and participation in church organizations and clubs) is a positive predicator of non-electoral political behavior (Wilcox and Gomez 1990). McVeigh and Sikkink (2001) found that religious beliefs play an indirect role in protest activity of churchgoing Protestants by affecting acceptance of such tactics.

The development and expansion of the Civil Rights movement of the late 1950s and 1960s was influenced by three trends directly affecting African Americans: (1) upward social mobility, (2) increased educational opportunities, and (3) the organizational expansion of black churches (Jenkins 1983; Lincoln and Mamiya 1990; McAdam 1982, 1983; Morris 1981). Black Americans have been socialized into both conventional and unconventional political practices (Harris 1999; Morris, Hatchet and Brown 1989; Secret and Welch 1982). For example, Harris states that "...boycotting, picketing and joining protest marches are just as legitimate a tool of political expression as voting, campaigning for candidates or contacting an elected official about a problem." (1999:9) Particularly in the rural south, churches have "traditionally served as gateways to other informal and formal social opportunities." (Ellison and Sherkat 1995: 1417)

Of particular importance to the discussion at hand is the multi-faceted role the black church has played in facilitating social and political action. The black church can provide a "cultural blueprint" for civic life and engagement (Patillo-McCoy 1998). Drawing on Swidler's (1986) influential concept of cultural "tool kits," Patillo-McCoy's (1998) study documents how church-based cultural practices permeate civic and political life. Churches have played a key role in the mobilization of blacks by providing the organizational and institutional resources 
Pulpits, Platforms and Protest among Black Americans • 1019

necessary for boycotts, sit-ins and other protest activities (Morris 1981). Clergy can direct members' action towards progressive causes and political action (Lee 2003). Additionally, churches provide a culturally legitimate forum from which moral and ethical opposition to oppression is cultivated and diffused (Harris 1999). Williams' (2002) study of politicized religious beliefs during the Civil Rights movement details the cultural process underlying mobilization. Williams argues that black churches created a "culture of hope that provided boycotters with a range of meanings which sustained their will to struggle..."(Williams 2002:212). From this perspective, black church culture can be conceptualized as an "interpretive resource" (Williams 2002) for mobilization and political action (Harris 1999; Williams 2002). Thus, the black church has played a central role in both the physical organization of political participation as well as the production of cultural practices and frames encouraging protest and conventional political participation.

Given the historical social and political importance of the black church, we expect that a key determinant of contemporary African Americans' protest activity is involvement with religious organizations. This expectation is further supported by recent empirical research on the relationship between the African American political activism and the church. Using data drawn from the 1993-4 National Black Politics Study, Brown and Brown (2003) examined the relationship between a range of political activities (both institutional and non-institutional behaviors) and church-based resources. The authors found that church attendance had a positive effect on protest activity net of controls. However, once measures of church activism and church political communication were added to the model, the original positive effect of church attendance is reduced to statistical insignificance. Thus, they demonstrate that it is not simply attending church that affects protest activity but rather it is the level of involvement in church activities and being exposed to political messages and discussions within a church community.

Black Americans who attend a church that exhibits a politicized church culture will be more likely to protest than those who attend a church that does not exhibit a politicized church culture.

\section{Organizational Involvement as an Impetus for Political Participation}

Persons with organizational ties may exhibit higher levels of political participation for reasons other than selective recruitment by social movement organizations. Research findings suggest that organizational members score high on measures of conventional political activity (Brady, Verba and Schlozman 1995; Verba and Nie 1972) and are more likely to vote in presidential primaries (Tate 1991), suggesting that selective recruitment is not the only factor relating organizational ties to political participation. Although specific causal factors will vary across organizations and types of political participation, organizational involvement may motivate political activity through a variety of mechanisms (Brady et al. 1995). For example, if the organization itself is involved in political activities, this political exposure may increase the political activity of individual members. Even if the organization itself is not politically oriented, affiliation may offer members a "wider view of the world" that will motivate political activity (Verba and Nie 1972:187).

Organizational involvement produces social capital which tends to promote political participation. Social capital is not a physically tangible resource, but rather it exists in the social relationships amongst actors (Coleman 1988); social networks have value, due to the "norms of reciprocity and trustworthiness that arise from them" (Putnam 2000:19). Social capital benefits the individual by providing useful social networks for human needs such as employment, 


\section{0 - Social Forces Volume 84, Number 2・December 2005}

assistance, and companionship. In addition to being a private good, Putnam suggests that elevated levels of social capital are also a "public good" because well-connected, civic-minded individuals improve the broader society. By their very nature, networks imply mutual obligations that serve to bond citizens together over a period of time, producing a general sense of reciprocity and a greater likelihood that individuals will work together to address commonly experienced problems or achieve common goals (Putnam 2000). Brown and Brown (2003) adopt a social capital model as an explanation for high rates of political activism amongst African American churchgoers. They assert that church attendance in general, and participation in the functions of the church in particular, should increase trust and obligations as individuals work toward similar goals. To the extent that church members fulfilling these obligations are exposed to political discussions, their political activism should increase (Brown and Brown 2003).

Social networks are expanded through organizational involvement and provide an important opportunity for recruitment into social movement and protest activity (McAdam and Paulsen 1993; Snow et al. 1980). Participation in one organization is likely to increase the likelihood of being asked to participate in another context or venue (Brady, Verba and Schlozman 1995; Oliver and Marwell 1992; Snow et al. 1986). Musick and colleagues found that effect of church attendance on volunteering is stronger for blacks than for whites (Musick et al. 2000). Citing Anderson (1996) the authors suggest that volunteering can be conceptualized as a continuum spanning from conventional to unconventional, with protest behavior falling into this latter category. The research findings of Verba and Nie (1972) provide evidence that not only does organizational involvement increase political participation, but also that this relationship is particularly strong for blacks. Whereas low social status may deter political activity by many minority individuals, black organizations can pool scarce resources, provide education on political matters to their members, and provide incentives and motivations to become a participant in politics (Tate 1991). Through these mechanisms, organizational involvement should increase political protest activity among Black Americans.

Black Americans with higher levels of organizational involvement will be more likely to protest than those with lower levels of organizational involvement.

\section{The Role of Group Identification: Black Consciousness and Black Power}

Tate (1991) suggests that, in addition to socioeconomic status, a central determinant of black political participation is group consciousness. Although measures of group consciousness vary, the most common measure approximates a Marxian notion of consciousness in which group members develop an awareness of their own status as a deprived group (Miller et al. 1981; Shingles 1981; Tate 1991; Verba and Nie 1972). Black group consciousness is argued to provide an ideology that drives poor blacks to participate more than poor whites in an effort to influence public policy in their favor (Shingles 1981). Strong empirical support for a relationship between black group consciousness and political participation is found in data from 1967 (Shingles 1981; Verba and Nie 1972), as well as in the elections of 1972 and 1976 (Miller et al. 1981), but less conclusive results were obtained from electoral data for 1984 and 1988 (Tate 1991). Using National Survey of Black Americans data from 1979-80, Ellison and London (1991) found that race consciousness was a significant predictor of black social and political participation.

Group consciousness, conceptualized as group identification and a feeling of collective location within a given stratification system, may not be the only motivational force that arises from organizational involvement among black Americans. For example, Smith (1981) argues that 
Pulpits, Platforms and Protest among Black Americans • 1021

feelings of "black power," defined as a call for blacks to set their own goals, lead their own organizations, and support those organizations, contributed to the development of racial solidarity, stimulated the development of black interest groups, and facilitated political participation among black Americans. Moreover, we suggest that individuals enmeshed in black organizational networks may be more likely to perceive that the Civil Rights movement was efficacious for improving the status of blacks and may be more likely to participate in politics. Because black empowerment movements have historically employed protest techniques and this process has been viewed as a legitimate mode of political behavior (Harris 1999; Morris, Hatchet and Brown 1989; Secret and Welch 1982), we expect group identification (i.e., black consciousness and black power) to be positively associated with political protest behavior.

Black Americans exhibiting higher levels of group identification are more likely to protest than those exhibiting lower levels of group identification.

\section{Research Questions}

Recent research has indicated the importance of church-based social capital in producing black political behaviors. Specifically, church activism and being active in church-based political communication were found to increase both electoral and non-electoral political activities (Brown and Brown 2003). An aim of this study is to determine whether the relationship between these church-based organizational activities and political protest is spurious. Consequently, we first examine whether church activism and church political communication are significant predictors of protest behavior net of relevant controls, measures of secular organizational participation, and black group identification.

Another goal of this study is to assess whether the relationship between church activism and protest, as well as the relationship between politicized church cultures and protest, are contingent upon other factors. In particular we seek to answer: (1) Are the effects of church activism and politicized church cultures on protest politics contingent upon secular organizational involvement? (2) Are the effects of church activism and politicized church cultures on protest politics contingent upon black group identification? (3) Are the effects of church activism and politicized church cultures on protest politics contingent upon one's level of education?

\section{Data, Measures and Methods}

The National Black Politics Study, conducted in 1993, was designed to provide information on attitudes and opinions regarding issues of importance to black Americans (Dawson, Brown and Jackson 1998). The sampling universe was all black households in the United States with telephones. A multiple frame, random-digit probability sampling procedure was undertaken in order to obtain an appropriate sample for analysis. The first frame was composed of a national random-digit-dial sample using an equal probability of selection methodology. The second frame was randomly selected from a list of households located in census blocks with 50 percent or more black households. Several tactics were used to increase response rates and lower non-response bias that can influence sample estimates. First, a call-back rule of an original call, plus a minimum of seven call backs was instituted. Second, all refusals were subject to refusal conversion attempts. In addition, only black interviewers were used. An overall response rate of 65.1 percent was achieved, and the resulting sample includes 1,206 black Americans ages 18 to 88. 


\section{2・Social Forces Volume 84, Number 2・December 2005}

A weighting procedure based on age, sex and region of residence was applied to the sample to more closely approximate a nationally representative sample. The weight variable was calculated by dividing the number of "expected respondents" for each sex/age/region category by the actual number of respondents for that category. The expected values are based on the United States Census Bureau population estimates for March 1994.

\section{Measures}

Previous research indicates that individuals who become involved in politics often undertake more than one of these activities (Verba and Nie 1972), yet there are different processes at work (Brady, Verba and Schlozman 1995). In this study, we examine a single dimension of political activity - protest behavior. This dependent variable indicates whether an individual has attended a protest meeting or demonstration, or taken part in a neighborhood march within the past year. Individuals participating in one or more of these activities are coded as "1." Individuals who have not taken part in any protest activities are coded as "0."

The independent variables represent both control variables and theoretical variables within our multivariate models. The set of control variables represents a number of standard predictors of political participation as well as demographic variables, including measures for age, gender, education and family income as utilized by Brown and Brown (2003). Male is the represented category for the dummy variable for gender. Education is operationalized through the use of a dummy variable for those individuals who have a college degree. No college degree is the reference category. Mean values were imputed for missing cases in the continuous variables for age and family income. In addition, we also introduce a range of variables culled from previous research that may affect protest participation. Additional indicators of biographical availability for protest (McCarthy and Zald 1973; Wiltfang and McAdam 1991) are controlled for by including measures of marital/relationship status, home ownership, whether or not the individual is a student, and labor force status. Other controls include region of residence, urban residence, union membership, political partisanship. See the Appendix for descriptions and coding schemes for these variables.

The next set of variables measures religious involvement and politicized church culture. McVeigh and Sikkink (1999) found that frequent church attendance increased the likelihood of participating in protest behavior relative to institutionalized politics. The church attendance variable represents the frequency in which respondents attended religious services. A measure of church activism reflects whether individuals were active participants in their church or place of worship through activities such as serving on committees and organizing meetings. Finally, a measure of politicized church culture reflects the extent to which political matters are integrated into their religious participation - i.e., the level of church-based political communication. This scale was composed of questions such as, "Has a member of the clergy or someone in an official position talked about the need for people to become more involved in politics?" and "Has any local or national political leader spoken at a regular religious service?" A complete description of the content and coding of these variables is presented in the Appendix.

We argue that a number of additional factors might substantially affect the protest behaviors of black Americans as well as potentially mediate the effect of religious involvement and politicized church cultures on these behaviors. Three of these measures involve organizational involvement. The first variable represents black organizational involvement and was created from a question asking individuals if they were members of any organization working to improve the status of black Americans. The next two organizational variables are church-related. One variable represents individuals that belong to churches or places of worship that provide community outreach programs such as a food and clothing 
Pulpits, Platforms and Protest among Black Americans • 1023

programs for the needy, substance abuse programs, a day care center or a senior center outreach program. A second variable reflects whether the respondents themselves were active in helping provide these outreach programs.

The final three variables can be roughly described as measures of black "group identification." The first of these variables was created from the question "Do you think that the movement for black rights has affected you personally?" The next two measures of group identification indicate a "political awareness or ideology" regarding a group's relative position in society as well as a shared interest or identification with one's one group (Miller et al. 1981:495). A "black consciousness" scale reflects an individual's awareness of antagonistic relations between social groups, the existence of illegitimate social barriers, and a sense of relative deprivation or discontent. The scale is composed of items such as "American society has provided black people a fair opportunity to get ahead in life." and, "America's big corporations are unfair to the black community." In addition, a scale labeled "Black Power" reflects the desire of black Americans "to define their own goals, to lead their own organizations, and to support those organizations." (Smith 1981:435) It indicates an individual's propensity to prefer black organizations, black stores, black schools and black control of the governance of mostly black communities. Essentially, the scale reflects a notion that blacks should rely on other blacks, rather than trusting other races or social groups. The coding of these variables and scales is listed in the Appendix.

\section{Methods}

Multivariate analyses to predict participation in protest activities are in the form of logit models (logistic regression). These models provide logit coefficients and odds-ratios reflecting the influence of the explanatory variables on the dichotomous outcome measure, involvement in protest politics.

Upon examining the distribution of the continuous variables included in the statistical analyses, it was found that a number of independent variables do not meet the assumption of normality. Transformations were applied to these variables to more closely approximate normality. Age is positively skewed, with a majority of the sample falling between the ages of 20 and 50, and a declining number of older respondents reaching age 88. A log transformation of age significantly reduced the skewness of this variable. The scale representing black consciousness was found to be negatively skewed. This scale was squared to more closely approximate a normal distribution. The multivariate analyses incorporate these transformed variables.

\section{Results}

\section{Descriptive Statistics}

An examination of the descriptive statistics in Table 1 provides an overview of relevant characteristics of the sample of black Americans. All statistics refer to untransformed variables. Approximately 55 percent of the sample is female, and the average age is slightly more than 41 years. The average number of years of education is 12.88 . About 30 percent of the sample has a college degree. Approximately 55 percent of the sample live in an urban area, and the same percentage own their residences. More than half the sample report strong political partisanship. Regarding the dependent variable, 40 percent of the respondents reported participation in protest activities. 
1024 Social Forces Volume 84, Number 2 - December 2005

Table 1: Descriptive Statistics for Full Sample

\begin{tabular}{|c|c|c|c|}
\hline & & $\mathrm{N}$ & $\%$ \\
\hline \multirow[t]{2}{*}{ Protest Behavior } & Yes & 482 & 40.1 \\
\hline & No & 720 & 59.9 \\
\hline \multirow[t]{2}{*}{ North Central } & Yes & 285 & 23.6 \\
\hline & No & 921 & 76.4 \\
\hline \multirow[t]{2}{*}{ Northeast } & Yes & 221 & 18.3 \\
\hline & No & 985 & 81.7 \\
\hline \multirow[t]{2}{*}{ South } & Yes & 665 & 55.1 \\
\hline & No & 541 & 44.9 \\
\hline \multirow[t]{2}{*}{ West } & Yes & 36 & 3.0 \\
\hline & No & 1170 & 97.0 \\
\hline \multirow[t]{2}{*}{ Sex } & Male & 540 & 44.8 \\
\hline & Female & 666 & 55.2 \\
\hline \multirow[t]{2}{*}{ Single } & Yes & 725 & 60.3 \\
\hline & No & 477 & 39.7 \\
\hline \multirow[t]{2}{*}{ Urban } & Yes & 666 & 55.4 \\
\hline & No & 537 & 44.6 \\
\hline \multirow[t]{2}{*}{ Not in the Labor Force } & Yes & 423 & 35.2 \\
\hline & No & 779 & 64.8 \\
\hline \multirow[t]{2}{*}{ Own Home } & Yes & 659 & 55.3 \\
\hline & No & 534 & 44.7 \\
\hline \multirow[t]{2}{*}{ College Degree } & Yes & 361 & 30.0 \\
\hline & No & 843 & 70.0 \\
\hline \multirow[t]{2}{*}{ Partisanship } & Yes & 806 & 77.1 \\
\hline & No & 239 & 22.9 \\
\hline \multirow[t]{2}{*}{ Student } & Yes & 71 & 5.9 \\
\hline & No & 1130 & 94.1 \\
\hline \multirow{2}{*}{ Union } & Yes & 336 & 28.2 \\
\hline & No & 856 & 71.8 \\
\hline \multirow[t]{2}{*}{ Black Organization } & Yes & 358 & 29.7 \\
\hline & No & 846 & 71.3 \\
\hline \multirow[t]{2}{*}{ Civil Rights Movement } & Yes & 857 & 71.3 \\
\hline & No & 345 & 28.7 \\
\hline \multirow[t]{2}{*}{ Church Activism } & Yes & 480 & 39.8 \\
\hline & No & 726 & 60.2 \\
\hline \multirow[t]{3}{*}{ Church Outreach } & Yes & 769 & 64.8 \\
\hline & No & 417 & 35.2 \\
\hline & & Mean & S.D. \\
\hline Age & & 41.13 & 16.02 \\
\hline Income & & 4.67 & 2.36 \\
\hline Church Attendance & & 1.80 & 1.19 \\
\hline Outreach Participation & & 1.07 & 1.15 \\
\hline Church Political Communication & & 2.32 & 2.15 \\
\hline Black Power & & 3.23 & 6.34 \\
\hline Black Consciousness & & 5.10 & 1.63 \\
\hline
\end{tabular}


Pulpits, Platforms and Protest among Black Americans • 1025

\section{Multivariate Analyses}

We hypothesize that the relationship between church resources and political activism reported by Brown and Brown (2003) might be spurious or overstated due to the absence of relevant control variables in their models. Consequently, in order to determine the robustness of this relationship, we include control variables for region of residence, marital/relationship status, home ownership, urban residence, relationship to the labor force, union membership, political partisanship and whether the individual is a student. Logistic regression models predicting involvement in protest activities are found in Table 2. The first model examines the effects of church attendance, church activism and church political communication net of relevant controls. Of the control variables two are statistically significant; living in the North Central region of the country is associated with lower rates of participation in political protest whereas claiming affiliation with a political party significantly increases protest activity. Moving to the variables of substantive interest we find that church attendance alone does not increase political protest, but actually has a significant negative effect. ${ }^{2}$ Church-based political communication and church involvement, however, have significant positive effects on protest behaviors. Thus, contrary to our expectations, the additional control variables do not mediate the relationship between church resources and political protest.

Model 2 adds theoretical variables measuring secular organizational ties, church-related organizational ties and measures of black "group identification." Two of these variables have significant effects on political protest. First, individuals that are members of any organization working to improve the status of black Americans are more than four times as likely to be involved in protest politics (the corresponding odds ratio is 4.30). Also, individuals who are active in church outreach programs are also significantly more likely to be involved in protest activities. Moreover, the inclusion of these variables mediates the effect of the church resources variables. While church political communication still exhibits a significant, although reduced, effect on protest, church activism is no longer a significant predictor of protest politics. Consequently, model 2 suggests that controlling for involvement in secular organizations and church involvement that focuses on outreach mediates the effect of church activism on protest politics. It seems that it is not active involvement in one's church, per se, that increase protest politics among black Americans. Instead, it is the more specific involvement in outreach programs targeting the community that is correlated with protest activities. ${ }^{3}$ It is important to note that none of the black "group identification" variables had a significant impact on protest behaviors.

The main effect models indicated that the measure reflecting church activism had a spurious effect on individual's involvement in political protests. The measure of church political communication, however, had a consistent positive effect on the dependent variable. The models testing interaction effects will examine if the relationship between church activism and protest, as well as the relationship between church political communication and protest, is contingent upon other characteristics of the individuals composing this nationally representative sample of black Americans. The moderating variables utilized in this analysis are whether or not the individual has a college degree and whether or not the individual is a member of an organization working towards the improvement of the lives of black Americans. ${ }^{4}$

Focusing on the effect of having obtained a college degree, we first examined the descriptive statistics for each group. These descriptive statistics, as well as the relevant chisquare values and t-statistics, are presented in Table 3. A number of significant differences were detected across these groups. Examining the chi-square statistics presented for the dichotomous variables, black Americans holding a college degree were more likely to be involved in protest politics, to be in the labor force, to own their homes, to be members of 
1026 - Social Forces Volume 84, Number 2 - December 2005

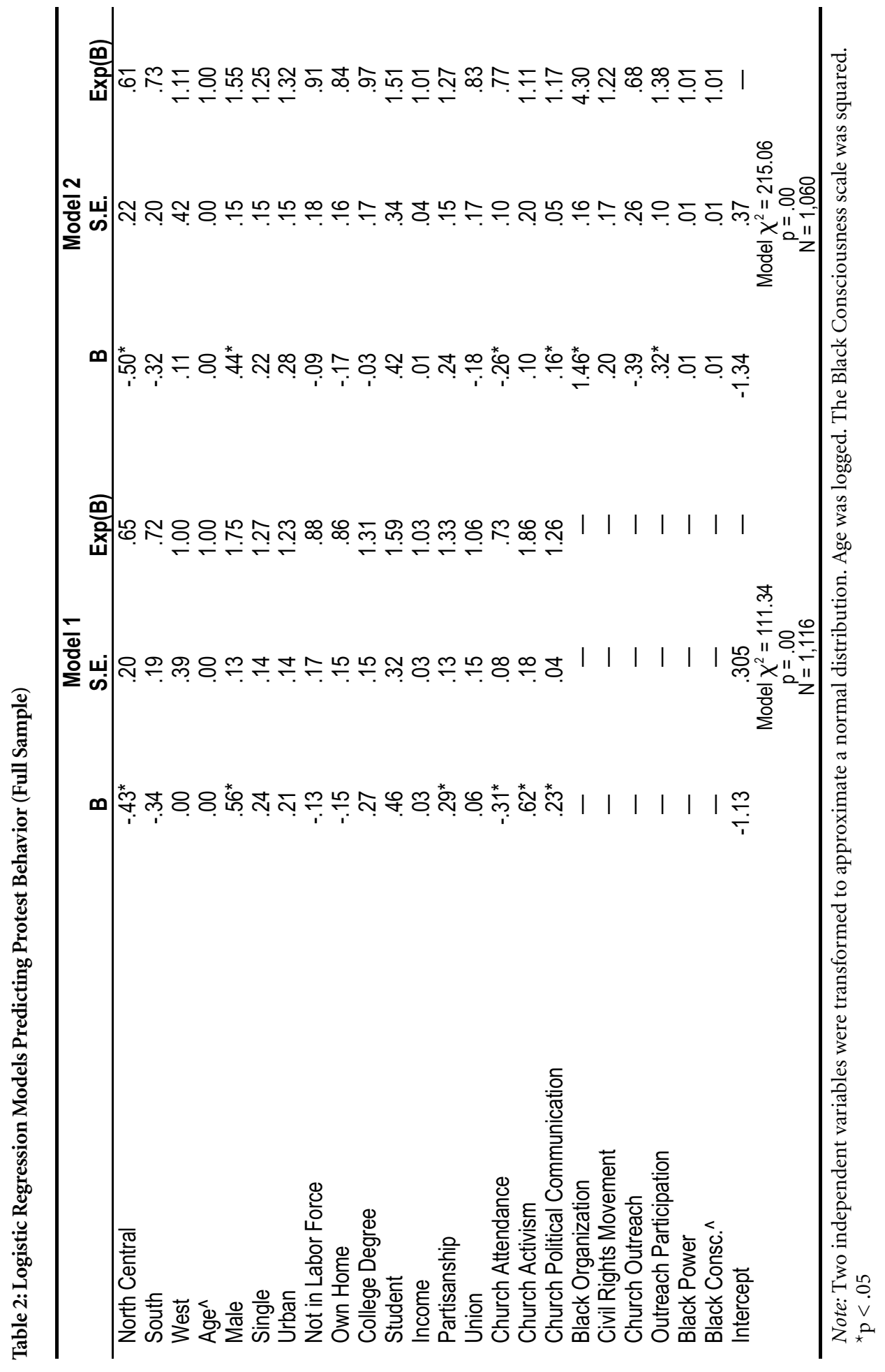


Pulpits, Platforms and Protest among Black Americans • 1027

black organization, to believe that the Civil Rights movement had affected them personally, and were more likely to be active in their churches or places of worship. Concerning the tstatistics testing the equality of the means of the continuous variables, those with a college degree have a higher income, are more likely to attend a church with community outreach programs, are more likely to be involved in these community outreach programs, and report higher levels of black consciousness. Based on these findings, it becomes obvious that having a college degree is of great importance - not only for our dependent variable of involvement in protest meetings, marches or demonstrations - but also for a number of independent variables that significantly influence protest politics. Consequently, we examine the conditioning effect of having a college degree in multivariate logistic regression models.

Table 4 includes separate models for individuals with and without a college degree. The corresponding coefficients from these models are then compared to test the null hypothesis of the equality of regression coefficients across the conditioning variable using $z$-tests. The proper formula for this test, as described by Clogg, Petkova and Haritou (1995) is as follows:

$$
\mathrm{Z}=\left(\beta_{1}-\beta_{2}\right) /\left[s^{2}\left(\beta_{1}\right)+s^{2}\left(\beta_{2}\right)\right]^{1 / 2}
$$

An absolute value of $\mathrm{Z}$ that is greater than 1.96 is statistically significant at an alpha level less than or equal to .05 .

Two interesting interaction effects are found amongst the control variables. First, being a student has a significant positive effect on protest for individuals without a college degree. In contrast, being a student has a negative, non-significant effect for individuals who do hold a degree. Although the type of student cannot be determined due to limitations in the questionnaire, these findings are compatible with the assertion that undergraduate students are more likely to be involved in protest, whereas graduate students and those seeking professional degrees are less likely to be active protestors. Second, claiming allegiance to one of the two major political parties significantly increases protest amongst those without a degree, but has no effect for individuals with a college degree. This difference is marginally significant $(p<.10)$.

Of particular interest is the possibility that the importance of church resource variables for increasing protest politics is contingent upon one's level of education. The models in Table 4 support this assertion. Church political communication has a positive, significant effect on protest politics only for individuals lacking a college degree $(\beta=.25, p<.05)$. This variable does not have a significant effect on protest for the college educated sample $(\beta=-.08)$, and the difference in coefficients across groups is statistically significant $(Z=-3.11, p<.05)$. Similar to the main effects models, church activism does not have a significant effect on protest for either group, although the effect is larger for individuals with a college degree and the difference in coefficients is marginally significant $(\mathrm{Z}=1.79, p<.10)$.

As the next step of our analysis, we examine the conditioning effect of membership in any organization working to improve the status of black Americans. As the first step of the analysis, the descriptive statistics for each group, as well as the relevant chi-square values and t-statistics, are presented in Table 5. Individuals belonging to a black organization are more than twice as likely to be involved in protest politics, and this difference is highly significant (chi-square $=147.89, p<.00$ ). The majority of the independent variables differ significantly as well. For example, those individuals who belong to a black organization are more likely to be male, tend to possess more resources (college degree, higher household income), are more active in their churches, and have a stronger black "group identity."

Separate models for those individuals who are members of a black organization and those who are not are presented in Table 6 . We are particularly interested in the possibility that the importance of church resource variables for increasing protest politics is contingent upon 
1028 - Social Forces Volume 84, Number 2 - December 2005

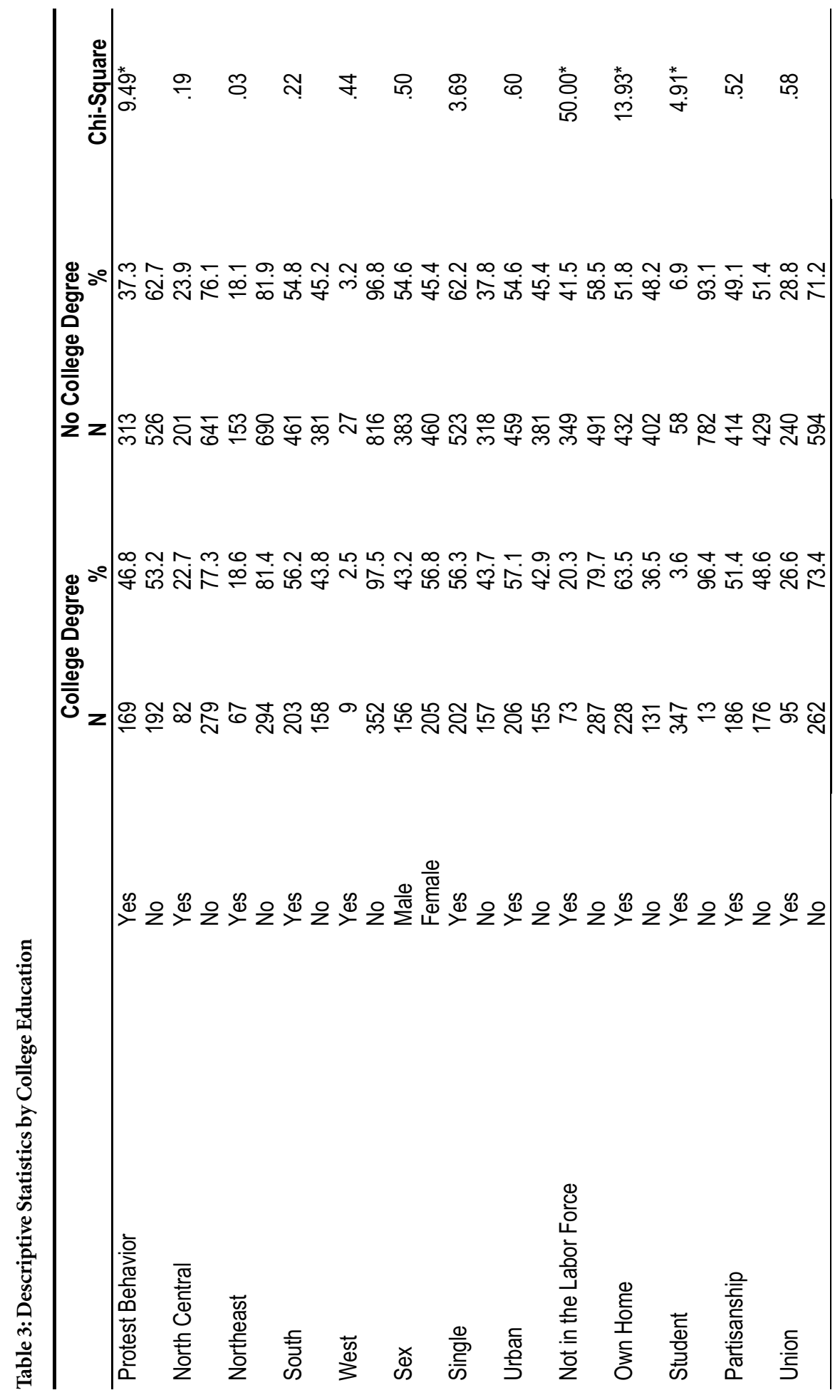


Pulpits, Platforms and Protest among Black Americans • 1029

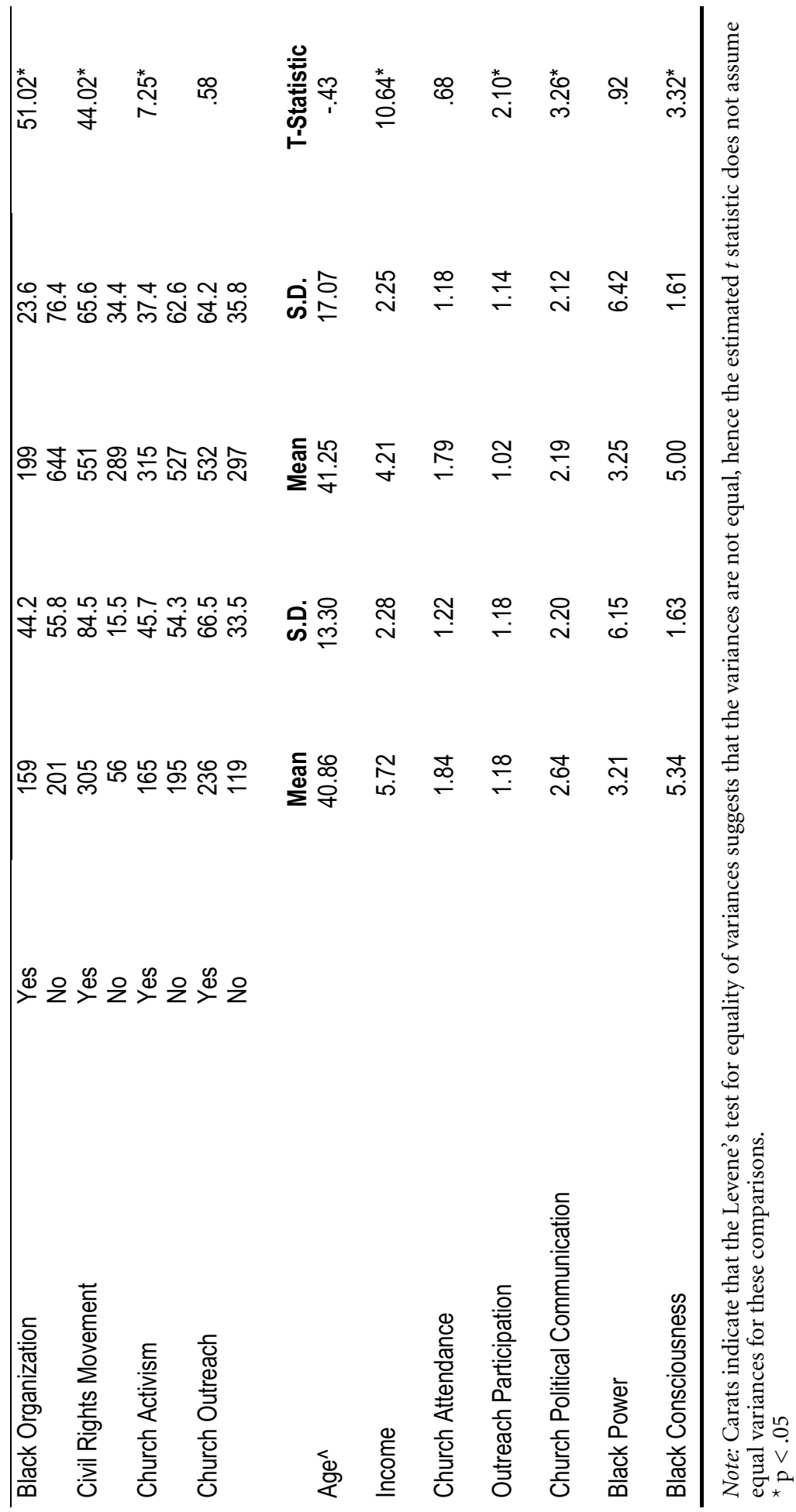


1030 - Social Forces Volume 84, Number 2 - December 2005

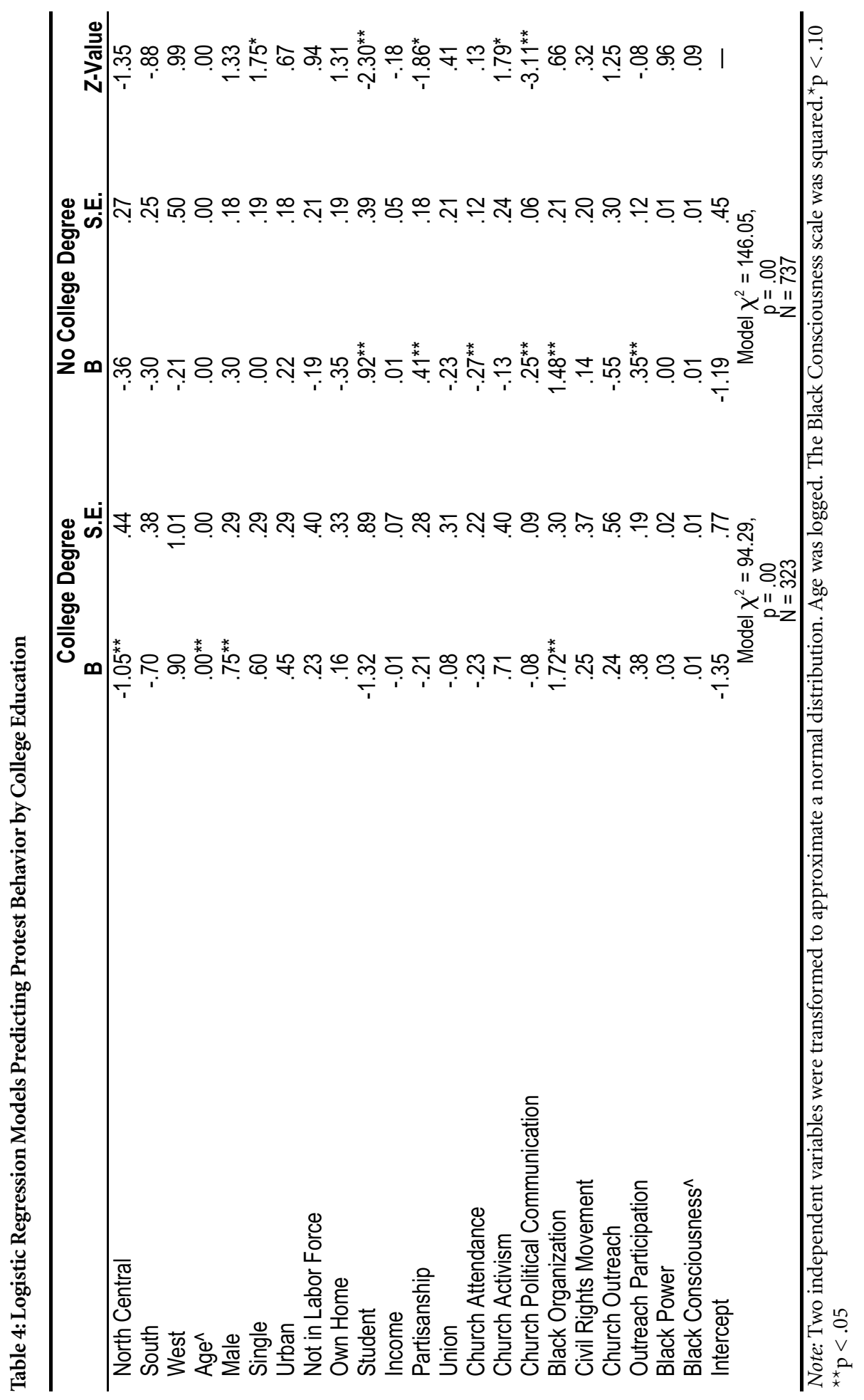


Pulpits, Platforms and Protest among Black Americans • 1031

one's membership in an organization working towards improving the status of black. Similar to the previous models, church activism does not have a significant impact on protest politics for either group. The effect of church political communication, on the other hand, is contingent upon one's membership in a black organization. Specifically, higher levels of political communication in one's church or place of worship increases protest behaviors only among those individuals who are not members of a black organization $(\beta=.21, p<.05)$. The difference in the magnitude of this coefficient across groups (the interaction effect) is moderately significant $(Z=-1.91, p<.10)$.

Building on the findings thus far, we further examined the contingent nature of the effect of church political communication on protest politics. As the final step of our analysis, we sharpen the contrast by comparing the subset of individuals in the sample who are both college educated and members of black organizations to the subset of individuals who are neither college educated nor members of black organizations. The descriptive statistics for these subsamples are presented in Table 7. Those individuals meeting both of the criteria are more than twice as likely to be involved in protest behaviors, and this difference is highly significant (chi-square $=81.26, p<.00$ ). Similar to the findings reflecting black organizational membership alone, the majority of the independent variables differ significantly across the subsamples. For example, those individuals with both a college degree and black membership are more likely to claim partisanship, be active in their churches, and believe that the Civil Rights movement affected them personally.

An examination of the multivariate models in Table 8 indicates that our independent variables are not useful predictors of protest activities amongst the 147 individuals that have a college degree and are members of a black organization. Only one coefficient, male, is significant and the overall model is not significant (chi-square $=23.93, p=.16$ ). In the comparison sample of individuals without a college degree and without black group membership, church political communication maintains a significant positive relationship with protest behaviors. Moreover, the effect of church political communication is significantly larger for this latter group $(\mathrm{Z}=-2.83, p<.05)$. Thus, political communication in one's church or place of worship is an impetus for protest politics only for black Americans who are less educated and who possess fewer organizational ties. As with the previous models, church activism does not predict protest politics for either group.

\section{Discussion and Conclusion}

The results of this analysis further clarify the role played by the black church in producing protest participation. In this analysis we focused on the relative importance of church attendance, church activism, a politicized church culture, organizational involvement and black consciousness. Simply attending church does not lead to protest participation. In fact, when other organizational measures and important control variables and are included in the statistical models we see that church attendance makes one less likely to engage in protest. In addition, our measures of black consciousness fail to have a significant impact on political protest for the entire sample or any of the subsamples.

Regarding church activism, model 1 (presented in Table 2) indicates that those who had served on a church committee, gave time to a special church project, or assisted in organizing church meetings were more likely to have participated in protest than respondents who were not active in their church. However, when additional measures were added, including measures of other organizational involvement, the significant positive effect of church activism disappears. In contrast, respondents who belong to organizations that are working to improve the status of black Americans are four times more likely to engage in protest than 
1032 - Social Forces Volume 84, Number 2 • December 2005

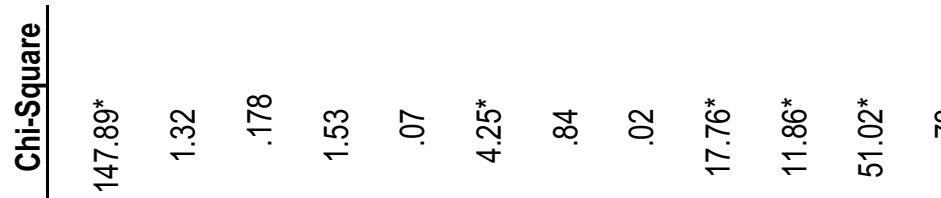

。

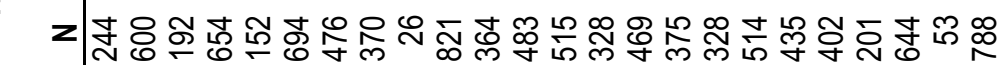

$0+\infty N 00+6 \infty N+\omega m N N \infty m N \infty N+600$

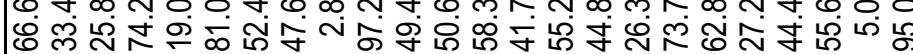

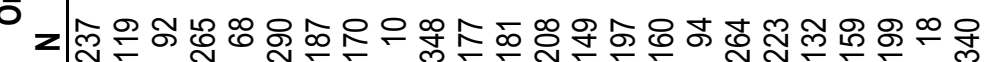

난

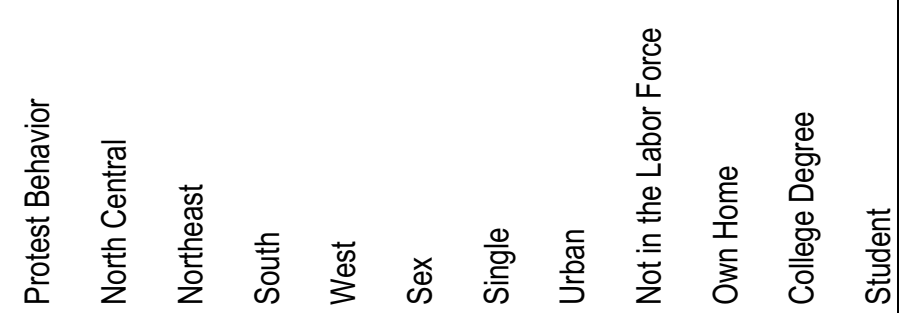




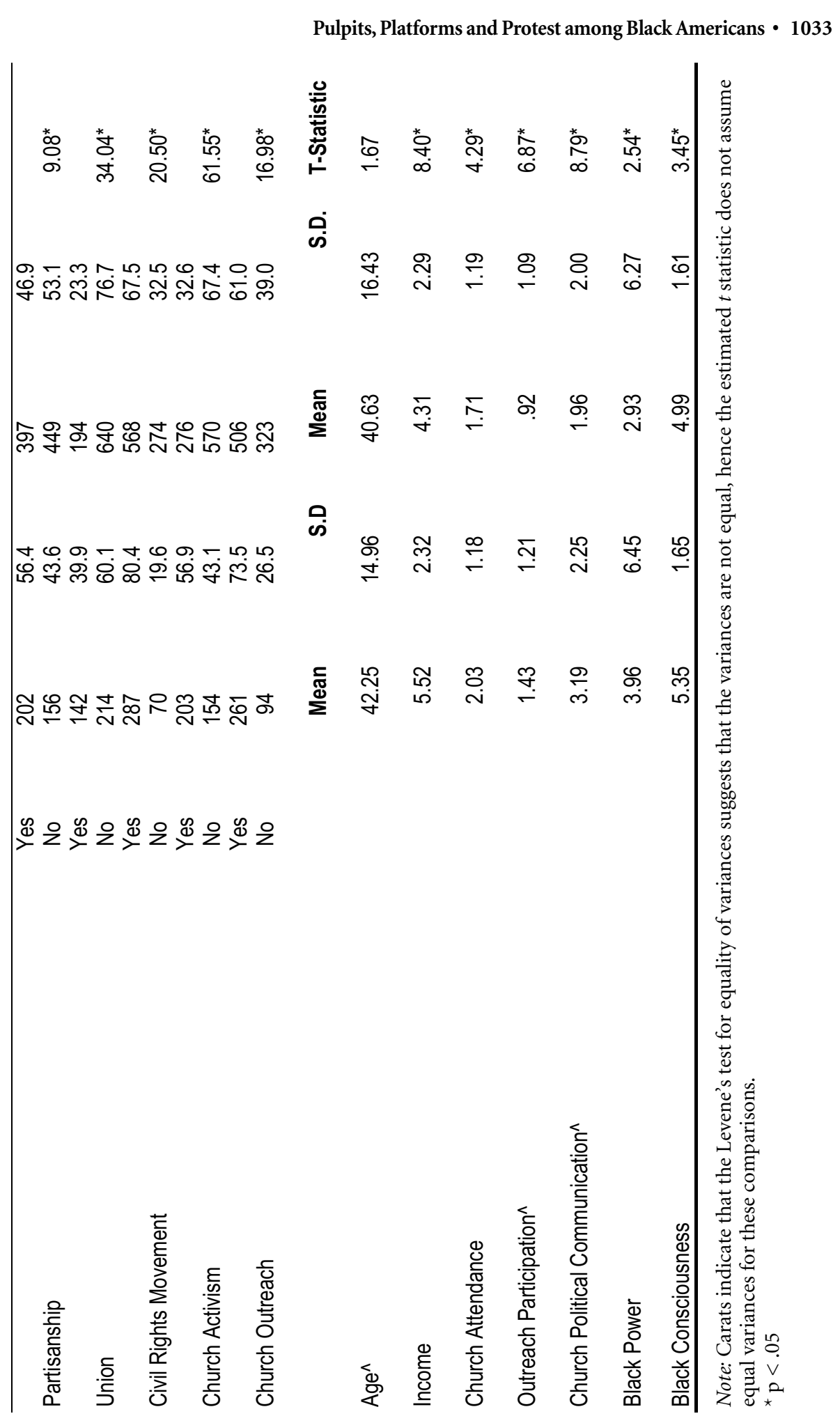


1034 - Social Forces Volume 84, Number 2 • December 2005

Table 6: Logistic Regression Models Predicting Protest Behavior by Membership in an Organization Working to Improve the Status of Black Americans

\begin{tabular}{|c|c|c|c|c|c|}
\hline & \multirow{2}{*}{\multicolumn{2}{|c|}{$\begin{array}{l}\text { Member of Black } \\
\text { Organization }\end{array}$}} & \multicolumn{2}{|c|}{ Not a Member } & \multirow{2}{*}{ Z-Value } \\
\hline & $B$ & & B & S.E & \\
\hline North Central & $-.84^{* *}$ & .41 & -.40 & .27 & -.90 \\
\hline South & -.35 & .38 & -.36 & .24 & .03 \\
\hline West & .24 & .93 & .01 & .50 & .22 \\
\hline Age & .00 & .00 & .00 & .00 & .00 \\
\hline Male & .42 & .27 & $.42^{* *}$ & .18 & -.01 \\
\hline Single & .24 & .28 & .25 & .19 & -.04 \\
\hline Urban & .45 & .28 & .21 & .18 & .73 \\
\hline Not in Labor Force & -.20 & .37 & -.01 & .21 & -.44 \\
\hline Own Home & -.44 & .31 & -.08 & .20 & -.99 \\
\hline College Degree & -.08 & .29 & -.04 & .21 & -.12 \\
\hline Student & -.07 & .72 & .51 & .38 & -.71 \\
\hline Income & -.02 & .07 & .03 & .05 & -.62 \\
\hline Partisanship & .29 & .28 & .21 & .18 & .25 \\
\hline Union & -.13 & .28 & -.23 & .22 & .28 \\
\hline Church Attendance & .04 & .23 & $-.34^{\star *}$ & .12 & 1.46 \\
\hline Church Activism & -.03 & .40 & .16 & .24 & -.42 \\
\hline Church Political & .01 & .09 & $.21^{* *}$ & .05 & $-1.91^{*}$ \\
\hline \multicolumn{6}{|l|}{ Communication } \\
\hline Civil Rights Movement & .34 & .34 & .13 & .20 & .54 \\
\hline Church Outreach & $-1.07^{* *}$ & .53 & -.14 & .30 & 1.53 \\
\hline Outreach Participation & $.58^{\star \star}$ & .18 & .21 & .12 & $1.74^{*}$ \\
\hline Black Power & .01 & .02 & .01 & .01 & 19 \\
\hline Black Consciousness & .01 & .01 & .01 & .01 & .09 \\
\hline \multirow[t]{4}{*}{ Intercept } & & .76 & -1.47 & .44 & - \\
\hline & \multicolumn{2}{|c|}{ Model $\chi^{2}=34.92$} & \multicolumn{2}{|c|}{ Model $\chi^{2}=51.01$} & \\
\hline & \multicolumn{2}{|c|}{$p=.04$} & \multicolumn{2}{|c|}{$p=.00$} & \\
\hline & \multicolumn{2}{|c|}{$\mathrm{N}=323}$. & \multicolumn{2}{|c|}{$\mathrm{N}=737}$. & \\
\hline
\end{tabular}

Note: Two independent variables were transformed to approximate a normal distribution. Age was logged. The Black Consciousness scale was squared.

${ }^{*} \mathrm{p}<.10 \quad{ }^{* *} \mathrm{p}<.05$

those who do not belong to any such organizations. This finding suggests that the positive effect of being active in one's church on protest participation is not a result of church involvement, but rather it reflects organizational involvement. In other words, church involvement does not necessarily lead to activism because of the religious nature or characteristics of the church. Activism is the result of a more general organizational process that facilitates political protest by providing resources, opportunities and incentives to members.

It is possible that our interpretation of these findings obscures the unique contribution of church activity. What if respondents who claimed membership in a black organization view their church as an organization working to improve the status of black Americans? If this is the case then the significant positive coefficient for black organization could reflect both church and non-church organizations. While we cannot completely rule out this possibility there are 
Pulpits, Platforms and Protest among Black Americans • 1035

two pieces of evidence that suggest this is not the case. First, we have included information about whether or not the respondent attends church and his or her level of church activity. Second, we have measures of whether or not the respondents' church has outreach programs, and if so, the respondents level of activity in these programs. With the inclusion of these variables, the effect of being involved in a black organization represents the unique contribution of this involvement net of the other activities.

In addition to producing a generalized organizational effect, churches can also facilitate protest by creating a politicized church culture. Respondents who hear political messages at church either from church leaders or invited guests and/or have been encouraged by clergy to get involved in political issues are more likely to engage in protest activity than those who are not exposed to these political messages. The presence of these political messages is the single strongest predictor of protest behavior in these data. Clearly the church plays an important role in producing protest behavior, but this is the case only when church members are exposed to political messages by church officials and practices.

These findings point to the continued significance of the church in the political lives of African Americans. The important role played by black churches during the Civil Rights movement in mobilizing political protest appears to have continued into the 1990s. By exposing those in attendance to political ideas and issues and providing opportunities for community involvement and outreach, churches can facilitate a wide range of political actions (Brown and Brown 2003) including political protest. Yet, as our analysis demonstrates, the effect of these variables is contingent upon education and organizational involvement. Specifically, being highly educated and/or being involved in other organizations that seek to advance the status of black Americans influences the relative importance of church involvement and activity in producing protest. Attending a church that exhibits a politicized church culture increases the likelihood of protest participation only for respondents who do not have a college degree. It is also the case that attending a church with a politicized church culture increases the likelihood of protest only for those respondents who are not members of organizations working to improve the status of black Americans. Taken together these findings demonstrate that the church serves as a crucial context for the dissemination of political messages and exposure to opportunities for protest only for those black Americans with lower educational attainment and organizational involvement.

Education level and organizational involvement are associated with both the likelihood of protest and with the mechanisms leading to protest. Sixty-six percent of respondents who have a college degree and hold membership in an organization working to improve the status of black Americans have participated in protest, while only 28 percent of respondents without a degree and without organizational involvement have protested. We see the differential effect of a politicized church culture most clearly by comparing those with a degree and organizational membership to those without either. Politicized church cultures are an impetus for protest politics only for black Americans with less formal education and fewer organizational ties.

This finding has implications for "social capital" explanations for the relationship between civic and political participation. Specifically, our findings suggest that the effect of different forms of social capital (i.e., secular and religious organizational participation) and human capital (i.e., education), is not necessarily additive. Rather, the impact of these varied forms of social capital on political activism appears to be complementary or contingent. For example, we found that political communication in one's church increases individual political activism only for those individuals lacking a college education or involvement in a secular organization working to improve the status of black Americans. Consequently, exposure to political communication through one's religious involvement did not further increase political participation for individuals possessing these other forms of capital. An optimistic conclusion drawn from our findings could 


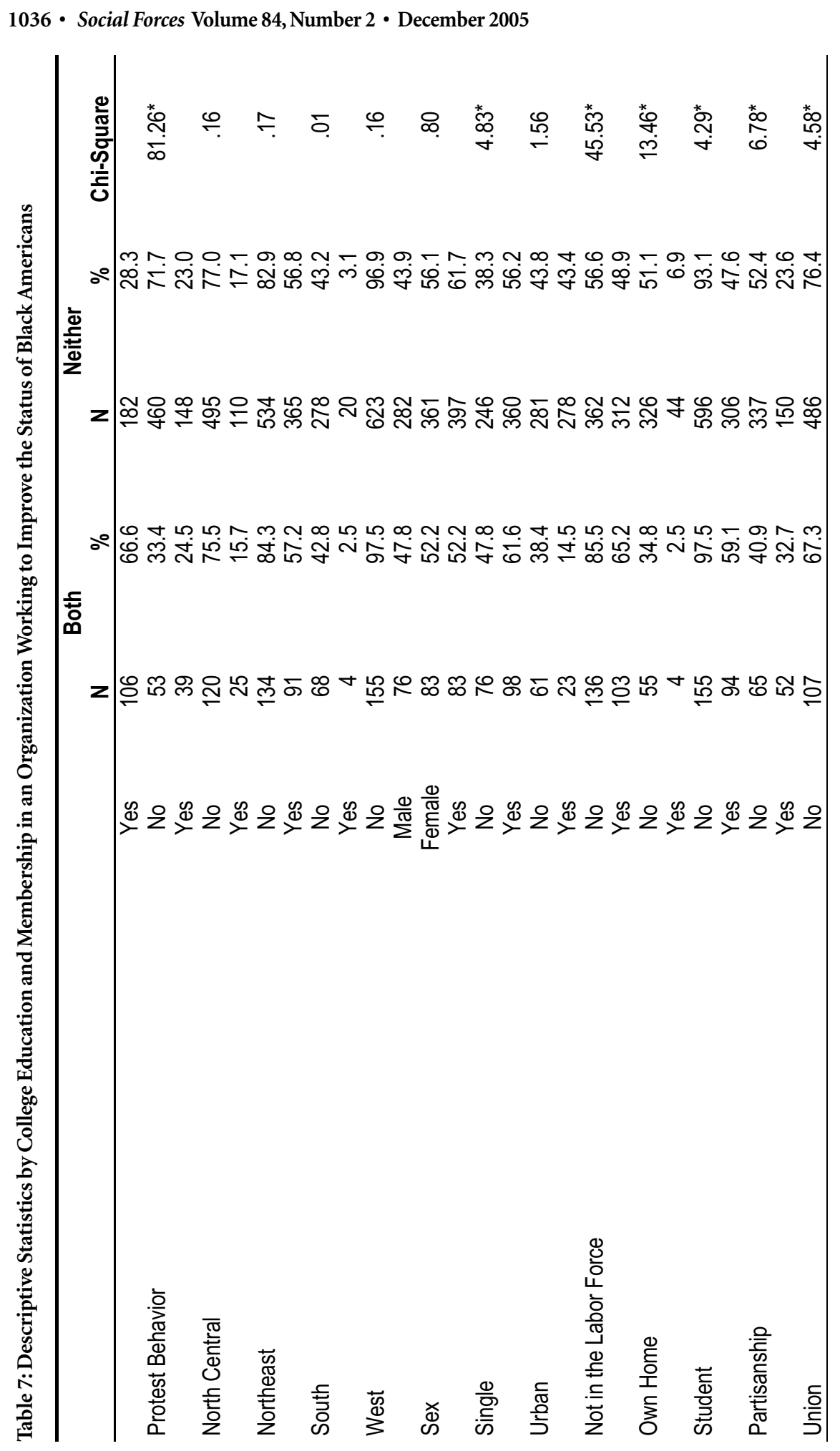




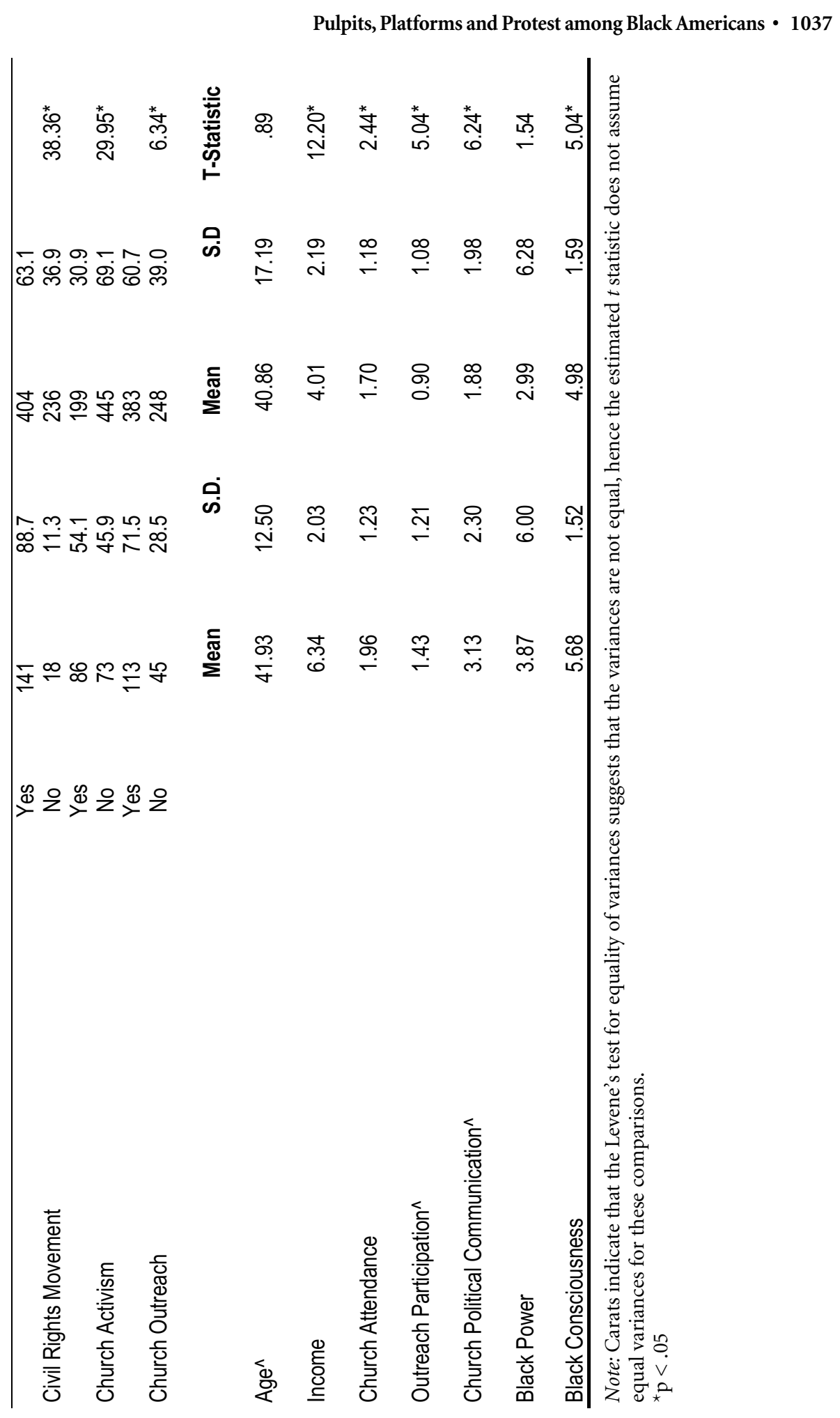


1038 - Social Forces Volume 84, Number 2 - December 2005

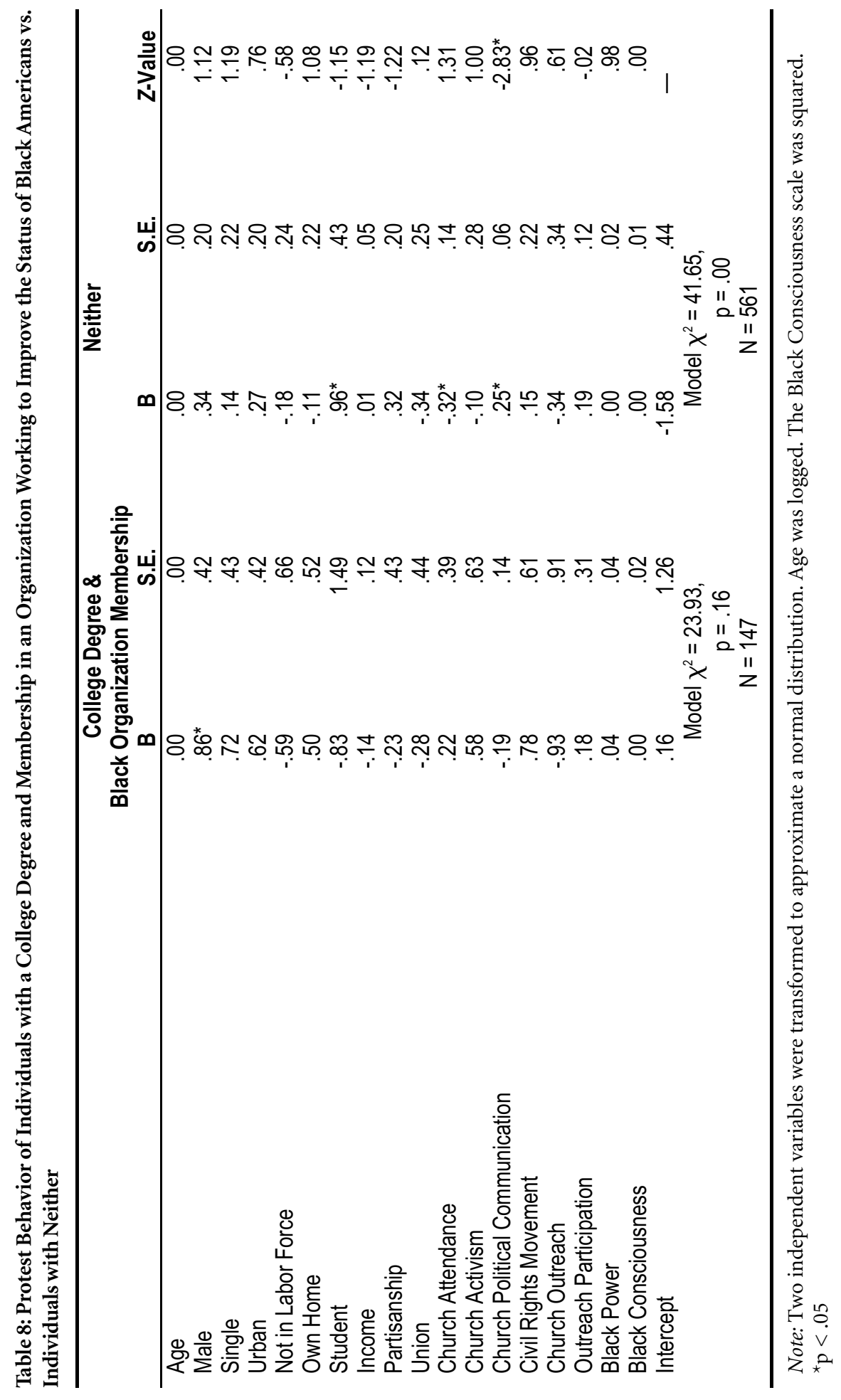


Pulpits, Platforms and Protest among Black Americans • 1039

be that political participation by black Americans is not precluded if one form of capital is missing. Instead, a number of forms of capital appear interchangeable. Consequently, participation will not be limited only to those with high SES, thereby making it more likely that the political issues being addressed cut across class interests. A more pessimistic conclusion points to the fact that exposure to political communication during the course of religious activities does not further promote political activism for black Americans possessing other forms of capital. Regardless, our findings suggest that future research on political participation from a social capital perspective should account for the potentially complex relationship between sources of social capital and participation.

This analysis also has implications for resource mobilization theory. Critics have argued that RMT does not deal adequately with the cognitive, ideational and cultural elements of movement participation (e.g., McAdam 1982; Melucci 1996; Snow et al. 1986; Taylor and Whittier 1995; Williams 2002, 2004). Building on this critique we expected to find that measures of group identification, which can be conceptualized as cultural indicators, would be significant predictors of protest behavior. The notion of group identification can potentially augment the resource mobilization perspective in a number of ways. First, the idea of group identification suggests that organizational membership may initiate an interactive process through which members may relate their own lived experiences to broader political phenomena. Thus, the resources gleaned from organizational membership may not be as important as an emergent process through which members draw a connection from their individual actions to the well-being of their social/racial/ethnic group. Calhoun-Brown (1996) found that group consciousness was a significant predictor of African American political activism. Resources and organization ties may have an inconsequential effect on political participation in comparison to the motivation resulting from the group consciousness that can emanate from an organization of like-minded individuals. These shared meanings and definitions of the black experience in modern America may provide strong motivations to seek social change through both conventional and unconventional political means (Miller et al. 1981). Moreover, these cultural frames may mediate the effect of organizational ties on participation. In other words, organizational involvement may be a consequential prerequisite for political action, but only through its impact on the shared meanings, ideas and sentiments that such involvement produces within its members. If this assertion is correct, cultural indicators such as black power and black consciousness may not only have significant effects on political participation, but they may also reduce the effects of the organizational variables to non-significance. Our findings do not support this hypothesis. The measures of black power and black consciousness were not significant predictors of protest behavior in any of the models suggesting that these psychological measures do not directly contribute to protest behavior.

Churches and other organizations are "sites of culture" (Williams 2004:130) that provide material and culture resources for participants and movements. Additional research is needed to further specify the relationship between church cultures, organizational resources and political protest. Culture "is patterned and patterning; it is enabling as well as constraining; and it is observable in linguistic practices, institutional rules and social rituals rather than existing only in people's minds." (Polletta 1999:67) While our study identifies the contingent importance of politicized church cultures in producing protest, data limitations prevent us from clearly specifying how, at the interpretative level, these cultures encourage or discourage protest.

Our findings clearly demonstrate that churches facilitate protest behavior by providing space and opportunity for political communication between members, the clergy and others. As Williams' study of mobilization in Arkansas during the Civil Rights era demonstrates "relational networks within the church house cultural resources that are central in generating and sustaining African American movement mobilization." (Williams 2002:208) Attending a church with a politicized culture and providing this type of communication is an important predictor of protest 


\section{0 • Social Forces Volume 84, Number 2・December 2005}

for African Americans without a college degree and with few organizational ties. For these respondents, attending a church with a politicized church culture appears to be the functional equivalent of membership in organizations working to improve the status of black Americans. Thus, churches continue to play an important institutional role for African Americans in the United States by providing organizational and cultural resources that encourage political protest.

The legacy of the Civil Rights movement, and the role of the black church in defining and challenging unjust social and political institutions, continues to be written. For example, grassroots movements have recently attempted to link environmental racism with broader questions of civil rights and justice (Bullard 1993, 2000). Blacks are disproportionately affected by environmental hazards and pollution, but are relatively absent in the environmental movement (Baugh 1991; Bullard 2000; Mohai 1990). This absence is, in part, due to the failure of mainstream environmentalists to address the racial dimensions of environmental issues (Baugh 1991; Bullard 1990). This deficiency is being rectified in part by grassroots movements in black and working-class communities that highlight the connections between environmental justice and social justice (Bullard 1990). Particularly in communities that do not have formal environmental organizations the role of the black church serves as a "useful vehicle for black communities fighting toxics." (Bullard 2000:91) Arp and Boeckelman (1997) find that church attendance and church activism are predictors of local environmental activism (including participation in protest activities). Future research should examine whether our model of general protest behavior is able to differentiate between the content of different protests. Does the effect of a politicized church culture on protest participation remain when the protests are addressing, say, environmental issues or homosexuality? If so, does this effect continue to be mediated by organizational involvement and educational level?

Finally, this study did not address the possible effects of individual religious affiliation or beliefs. Using nationally representative data, McVeigh and Smith (1999) found that religious affiliation distinguishes participants in protest politics from those participating only in institutional politics. However, religious affiliation did differentiate between participants in protest politics and those not engaged in either kind of behavior. An analysis of churchgoing Protestants revealed that religious beliefs can lead to protest behavior by influencing the approval of contentious tactics (McVeigh and Sikkink 2001). Future studies should examine how religious affiliation and beliefs may mediate the effects of organizational resources on protest behavior.

\section{Notes}

1. We thank an anonymous Social Forces reviewer for suggesting this terminology.

2. Brown and Brown (2003) find that when church activism and church political communication are included in the model, the positive church attendance effect becomes statistically insignificant. The discrepancy between their findings and ours may result from the different coding of the dependent variable and/or the inclusion of additional control variables, which revealed that church attendance does indeed have a significant negative effect on protest participation.

3. The "outreach participation" question is only asked of individuals who report that their church or place of worship provides community outreach programs such as a food and clothing program for the needy, a substance abuse program, a car care center or a senior center. Consequently, individuals answering affirmatively to this question not only attend churches that focus on community outreach (represented by the variable "church outreach"), but they are also active participants in community outreach. 
Pulpits, Platforms and Protest among Black Americans • 1041

4. We assumed that politically relevant variables such as partisanship might have significant moderating effects on the church resource variables, but this was not the case. We also tested for moderating effects across gender, urban vs. rural, labor force participation, years of education, black consciousness and black power. These variables did not significantly moderate the effect of church resources on protest participation.

\section{References}

Anderson, Christopher. 1996. "Political Action and Social Integration." American Politics Quarterly 24:105-25.

Arp, William III, and Keith Boeckelman. 1997. "Religiosity: A Source of Black Environmentalism and Empowerment?" Journal of Black Studies 28:255-67.

Baer, Hans A., and Merrill Singer. 1992. African-American Religion in the Twentieth Century: Varieties of Protest and Accommodation. University of Tennessee Press.

Baugh, Joyce A. 1991. "African-Americans and the Environment: A Review Essay" Policy Studies Journal 19:182-91.

Beyerlein, Kraig, and Mark Chaves. 2003. "The Political Activities of Religious Congregations in the United States." Journal for the Scientific Study of Religion 42:229-46.

Billings, Dwight B., and Shaunna L. Scott. 1994. "Religion and Political Legitimation." Annual Review of Sociology 20:173-201.

Brady, Henry E., Sidney Verba and Kay Lehman Schlozman.1995. "Beyond SES: A Resource Model of Political Participation." American Political Science Review 89:271-94.

Brown, R. Khari, and Ronald E. Brown. 2003. "Faith and Works: Church-Based Social Capital Resources and African American Political Activism." Social Forces 82:617-41.

Bullard, Robert D. 1993. "Anatomy of Environmental Racism and the Environmental Justice Movement" Pp. 15-40. Confronting Environmental Racism: Voices from the Grassroots. Robert D. Bullard, editor. South End Press.

2000. Dumping in Dixie: Race, Class, and Environmental Quality. $3^{\text {rd }}$ edition. Westview Press.

Calhoun-Brown, Allison. 1996. "African American Churches and Political Mobilization: The Psychological Impact of Organizational Resources." The Journal of Politics 58:935-53.

Chaves, Mark. 1999. "Religious Congregations and Welfare Reform: Who Will Take Advantage of 'Charitable Choice'?" American Sociological Review 64:836-46.

2004. Congregations in America. Harvard University Press.

Clogg, Clifford C., Eva Petkova and Adamantios Haritou. 1995. "Statistical Methods for Comparing Regression Coefficients Between Models." American Journal of Sociology 100: 1261-1293.

Coleman, James. 1988. "Social Capital in the Creation of Human Capital." American Journal of Sociology 94:S95-S120.

Cress, Dan, and David Snow. 1996. "Resources, Benefactors, and the Viability of Homeless SMOs." American Sociological Review 61:1089-109.

Dawson, Michael, Ronald Brown and James S. Jackson. 1994. National Black Politics Study, 1993 [Computer File]. ICPSR version. Chicago, IL: University of Chicago, Wayne State University, University of Michigan, producers. Inter-University Consortium for Political and Social Research [distributor], 1998. 


\section{2・Social Forces Volume 84, Number 2・December 2005}

Ellison, Christopher G., and Bruce London. 1992. "The Social and Political Participation of Black Americans: Compensatory and Ethnic Community Perspectives Revisited." Social Forces 70:681-701.

Ellison, Christopher G., and Darren E. Sherkat. 1995. "The 'Semi-Involuntary Institution Revisited: Regional Variations in Church Participation among Black Americans." Social Forces 73:1415-37.

Fantasia, Rick. 1988. Cultures of Solidarity: Consciousness, Action, and Contemporary American Workers. University of California Press.

Fowler, Robert Booth, Allen D. Hertzke and Laura R. Olson. 1999. Religion and Politics in America: Faith, Culture, and Strategic Choices. Second Edition. Westview Press.

Gallup, George Jr., and Jim Castelli. 1989. The Peoples Religion: American Faith in the 90s. MacMillan.

Geschwender, James A. 1964. "Explorations in the Theory of Social Movements and Revolutions" Pp. 6-17. The Black Revolt. James A. Geschwender, editor. Prentice-Hall.

Goodwin, Jeff, and James M. Jasper. 2003. Rethinking Social Movements: Structure, Culture, and Emotion Rowman \& Littlefield.

Gusfield, Joseph. 1970. Protest, Reform, and Revolt. John Wiley \& Sons.

Harris, Fredrick. 1999. Something Within. Oxford University Press.

Hunt, Larry L., and Janet G. Hunt. 1977. "Black Religion as BOTH Opiate and Inspiration of Civil Rights Militance: Putting Marx's Data to the Test." Social Forces 56:1-14.

Jenkins, J. Craig. 1983. "Resource Mobilization Theory and the Study of Social Movements." Annual Review of Sociology 9:527-53.

Johnston, Hank. 1991. Tales of Nationalism: Catalonia, 1939-1979. Rutgers University Press.

Johnston, Hank, and Bert Klandermans. 1995. "The Cultural Analysis of Social Movements." Pp. 3-24. Social Movements and Culture. Hank Johnston and Bert Klandermans, editors. University of Minnesota Press.

Kornhauser, William. 1959. The Politics of Mass Society. The Free Press.

Lee, Shayne. 2003. "The Church of Faith and Freedom: African-American Baptists and Social Action." Journal for the Scientific Study of Religion 42:31-42.

Lincoln, C. Eric, and Lawerence H. Mamiya. 1990. The Black Church in the African American Experience. Duke University Press.

Lipset, Seymour Martin, and Sheldon S. Wolin. 1965. The Berkeley Student Revolt. Doubleday.

Marx, Gary T. 1967. "Religion: Opiate of Inspiration of Civil Rights Militancy Among Negroes?" American Sociological Review. 32:64-72.

McAdam, Doug. 1982. Political Process and the Development of Black Insurgency, 1930-1970. University of Chicago Press.

1983. "Tactical Innovation and the Pace of Black Insurgency Between 1955 and 1970." American Sociological Review 48:735-54.

1986. "Recruitment to High-Risk Activism: The Case of Freedom Summer." American Journal of Sociology 92:64-90.

1996. "The Framing Function of Movement Tactics: Strategic Dramaturgy in the American Civil Rights Movement." Pp. 338-56. Comparative Perspectives on Social Movements. Doug McAdam, John D. McCarthy and Mayer N. Zald, editors. Cambridge University Press. 
Pulpits, Platforms and Protest among Black Americans • 1043

McAdam, Doug, John D. McCarthy and Mayer N. Zald. 1996. "Introduction: Opportunities, Mobilizing Structures, and Framing Processes - Towards a Synthetic, Comparative Perspective on Social Movements." Pp. 1-20. Comparative Perspectives on Social Movements. Doug McAdam, John D. McCarthy and Mayer N. Zald, editors. Cambridge University Press.

McAdam, Doug, and Ronelle Paulsen. 1993. "Specifying the Relationship Between Social Ties and Activism." American Journal of Sociology 99:640-67.

McCarthy, John D., Jackie Smith and Mayer N. Zald. 1996. "Accessing Public, Media, Electoral, and Governmental Agenda." Pp. 291-311. Comparative Perspectives on Social Movements. Doug McAdam, John D. McCarthy and Mayer N. Zald, editors. Cambridge University Press.

McCarthy, John D., and Mayer N. Zald. 1977. "Resource Mobilization and Social Movements: A Partial Theory." American Journal of Sociology 82:1212-41.

2002. "The Enduring Vitality of the Resource Mobilization Theory of Social Movements." Pp. 533-65. Handbook of Sociological Theory. Jonathan H. Turner, editor. Kluwer Academic/Plenum Publishers.

McPhail, Clark. 1971. "Civil Disorder Participation: A Critical Examination of Recent Research". American Sociological Review 36:1058-73.

McPhail, Clark, and David Miller. 1973. "The Assembling Process: A Theoretical and Empirical Examination." American Sociological Review 38:721-35.

McVeigh, Rory, and David Sikkink. 2001. "God, Politics, and Protest: Religious Beliefs and the Legitimation of Contentious Tactics." Social Forces 79:1425-58.

McVeigh, Rory, and Christian Smith. 1999. "Who Protests in America: An Analysis of Three Political Alternatives - Inaction, Institutionalized Politics, or Protest." Sociological Forum 14:685-702.

Melucci, Alberto. 1989. Nomads of the Present: Social Movements and Individual Needs in Contemporary Society. Temple University Press.

1996. Challenging Codes: Collective Action in the Information Age. Cambridge University Press.

Miller, Arthur H., Patricia Gurin, Gerald Gurin and Oksana Malanchuk. 1981. "Group Consciousness and Political Participation." American Journal of Political Science 25:494-511.

Mohai, Paul. "Black Environmentalism." Socia/ Science Quarterly 71:745-765.

Morris, Aldon. 1981. "Black Southern Student Sit-In Movement: An Analysis of Internal Organization." American Sociological Review 46:744-67.

1984. Origins of the Civil Rights Movement: Black Communities Organizing for Change. Free Press.

Morris, Aldon D., Shirley J. Hatchett and Ronald E. Brown. 1989. "The Civil Rights Movement and Black Political Socialization." Pp. 272-305. Political Learning in Adulthood: Constancy and Change. Robert Sigel, editor. University of Chicago Press.

Morris, Aldon D., and Carol Mueller, editors. 1992. Frontiers in Social Movement Theory. Yale University Press.

Mueller, Carol. 1994. "Conflict Networks and the Origins of Women's Liberation." Pp. 234-63. Enrique Larana, Hank Johnston and Joseph R. Gusfield, editors. New Social Movements From Ideology to Identity. Temple University Press.

Musick, Marc, John Wilson and William Bynum. 2000. "Race and Formal Volunteering: The Differential Effects of Class and Religion." Social Forces 78:1539-71.

Oliver, Pamela E., and G. Marwell. 1992. "Mobilizing Technologies for Collective Action." Pp. 251-72. Frontiers in Social Movement Theory. Aldon D. Morris and Carol McClurg Mueller, editors. Yale University Press. 


\section{4・Social Forces Volume 84, Number 2・December 2005}

Orum, Anthony M. 1972. Black Students in Protest. Washington D.C.: American Sociological Association.

Pattillo-McCoy, Mary. 1998. "Church Culture as a Strategy of Action in the Black Community." American Sociological Review 63:767-84.

Payne, Charles M. 1995. I've Got the Light of Freedom: The Organizing Tradition and the Mississippi Freedom Struggle. University of California Press.

Piven, Frances Fox, and Richard A. Cloward. 1977. Poor People's Movements. Pantheon.

Polletta, Francesca. 1997. "Culture and Its Discontents: Recent Theorizing on the Cultural Dimensions of Protest." Sociological Inquiry 67:431-50.

1999. "Snarls, Quacks, and Quarrels: Culture and Structure in Political Process Theory." Sociological Forum 14(1)63-70.

Putnam, Robert D. 2000. Bowling Alone: The Collapse and Revival of American Community. Simon \& Schuster.

Robnett, Belinda. 1997. How Long? How Long?: African-American Women in the Struggle for Civil Rights. Oxford University Press.

Secret, Phillip E., and Susan Welch. 1982. "Race and Political Protest: A Longitudinal Analysis." Journal of Black Studies 12:351-62

Secret, Phillip E., James B. Johnson and Audrey W. Forrest. 1990. "The Impact of Religiosity on Political Participation and Membership in Voluntary Associations Among Black and White Americans." Journal of Black Studies 21:87-102.

Shingles, Richard D. 1981. "Black Consciousness and Political Participation: The Missing Link." The American Political Science Review 75:76-91.

Smith, Christian 1996. "Correcting a Curious Neglect, or Bringing Religion Back In." Pp. 1-28. Disruptive Religion: The Force of Faith in Social-Movement Activism. Christian Smith, editor. Routledge.

Smith, Robert C. 1981. "Black Power and the Transformation from Protest to Policies." Political Science Quarterly 96:431-43.

Snow, David A., Louis A. Zurcher and Sheldon EcKland-Olson. 1980. "Social Networks and Social Movements: A Microstructural Approach to Differential Recruitment." American Sociological Review 45:787-801.

Snow, David A., Burke E. Rochford, Jr., Steven K. Worden and Robert D. Benford. 1986. "Frame Alignment Processes, Micromobilization, and Movement Participation." American Sociological Review 51:46481.

Swidler, Ann. 1986. "Culture in Action: Symbols and Strategies." American Sociological Review 51:273-86.

1995. "Cultural Power and Social Movements." Pp.25-40. Social Movements and Culture. Hank Johnston and Bert Klandermans, editors. University of Minnesota Press.

Tate, Katherine. 1991. "Black Political Participation in the 1984 and 1988 Presidential Elections." The American Political Science Review 85:1159-76.

Taylor, Verta. 1989. “Social Movement Continuity." American Sociological Review 54:761-75.

Taylor, Verta, and Nancy Whittier. 1995. "Analytical Approaches to Social Movement Culture: The Culture of the Women's Movement." Pp. 163-87. Social Movements and Culture. Hank Johnston and Bert Klandermans, editors. University of Minnesota Press.

Turner, Ralph H., and Lewis Killian. 1957. Collective Behavior. Prentice-Hall. 
Pulpits, Platforms and Protest among Black Americans • 1045

Verba, Sidney, and Norman Nie. 1972. Participation in America. Harper \& Row.

Verba, Sidney, Kay L. Schlozman and Henry E. Brady. 1995. Voice and Equality: Civic Voluntarism in American Politics. Harvard University Press.

Wald, Kenneth D. 2003. Religion and Politics in the United States. Rowman \& Littlefield.

Wilcox, Clyde, and Leopoldo Gomez. 1990. "Religion, Group Identification, and Politics Among Black Americans." Sociological Analysis 51:271-86.

Williams, Johnny E. 2002. "Linking Beliefs to Collective Action: Politicized Religious Beliefs and the Civil Rights Movement." Sociological Forum 17:203-22.

2004. "Vanguards of Hope: The Role of Culture in Mobilizing African-American Women's Social Activism in Arkansas." Sociological Spectrum. 24:129-56.

Wiltfang, Gregory L., and Doug McAdam. 1991. "The Costs and Risks of Social Activism: A Study of Sanctuary Movement Activism." Social Forces 69:987-1010. 
1046 - Social Forces Volume 84, Number 2 - December 2005

\section{APPENDIX: Descriptions of Variables and Scales}

\section{Protest Behavior:}

In the last 2 years have you:

- Attended a protest meeting or demonstration?

- Taken part in a neighborhood march?

Individuals answering yes to either or both of these questions were coded "1."

Individuals answering no to both of these questions were coded " 0 ."

\section{Region:}

Northeast (reference category): Connecticut, Maine, Massachusetts, New Hampshire, New Jersey, New York, Pennsylvania, Rhode Island, Vermont

North Central: Illinois, Indiana, lowa, Kansas, Michigan, Minnesota, Missouri, Nebraska, North Dakota, Ohio, South Dakota, Wisconsin

South: Alabama, Arkansas, Delaware, District of Columbia, Florida, Georgia, Kentucky, Louisiana, Maryland, Mississippi, North Carolina, Oklahoma, South Carolina, Tennessee, Texas, Virginia, West Virginia

West: Alaska, Arizona, California, Colorado, Hawaii, Idaho, Montana, Nevada, New Mexico, Oregon, Utah, Washington, Wyoming

\section{Gender:}

Male $=1$

Female $=0$

\section{Single:}

Widowed, Separated, Divorced, Never Married $=1$ Married or Living with Significant Other $=0$

Urban:

Live in Large City $=1$

Live in Rural or Country Area, Small Town, Small City or Suburb $=0$

\section{Not in Labor Force:}

Working Fulltime or Working Parttime $=1$

Laid-Off, Unemployed, Retired, Homemaker, Student or Permanently Disabled = 1

\section{Own Home:}

Own or Buying $=1$

Paying rent or Other $=0$

College:

Do you have a college degree? $($ Yes $=1$, No $=0)$

\section{Student:}

In your main activity are you a student? $(\mathrm{Yes}=1, \mathrm{No}=0)$ 
Income:

Which of the following income groups includes your total family income in 1992 before taxes?

$\begin{array}{ll}\text { Up to } \$ 10,000= & 1 \\ \$ 10,000-\$ 14,999= & 2 \\ \$ 15,000-\$ 19,999= & 3 \\ \$ 20,000-\$ 24,999= & 4 \\ \$ 25,000-\$ 29,999= & 5 \\ \$ 30,000-\$ 39,999= & 6 \\ \$ 40,000-\$ 49,999= & 7 \\ \$ 50,000-\$ 59,999= & 8 \\ \$ 75,000 \text { and over }= & 9\end{array}$

\section{Partisanship:}

Would you consider yourself a strong Republican or a strong Democrat? $(Y e s=1, \mathrm{No}=0)$

\section{Union Membership:}

Does anyone in this household belong to a labor union? $(\mathrm{Yes}=1, \mathrm{No}=0)$

\section{Black Organization:}

Are you a member of any organization working to improve the status of black Americans? $($ Yes $=1$, No $=0)$

\section{Civil Rights Movement:}

Do you think that the movement for black rights has affected you personally? (Yes $=1$, No $=0$ )

\section{Church Attendance:}

How often do you attend religious services? (Never $=0$, once or twice a year $=1$, once or twice a month $=2$, at least once a week $=3$ )

\section{Church Activism:}

In the past 12 months have you been an active member of your church or place of worship? I mean, have you served on a committee, given time to a special project, or helped to organize a meeting? (Yes $=1, \mathrm{~N}_{0}=0$ )

\section{Church Outreach:}

Does your church or place of worship provide community outreach programs such as a food program and clothing program for the needy, a drug or alcohol abuse program, a day care center or nursery, or a senior center outreach program? (Yes $=1, \mathrm{No}=0)$

\section{Outreach Participation:}

How active are you in helping to provide your churches outreach programs? (Not at all active $=0$, not very active $=1$, fairly active $=2$, very active $=3$ )

\section{Church Political Communication $(\mathrm{a}=.843)$ :}

- In the last year, have you heard any discussions of politics at your church or place or worship?

- Have you talked to people about political matters at your church or place or worship?

- Has a member of the clergy or someone in an official position talked about the need for people to become more involved in politics? 
1048 - Social Forces Volume 84, Number 2 • December 2005

- Has any local or national political leader spoken at a regular religious service?

- Has a member of the clergy, or someone in an official position, ever suggested that you vote for or against certain candidates?

- What about suggesting that you take some other action on a political issue - sign a petition, write a letter, go to a meeting, attend a protest, march or demonstration, or get in touch with a public official?

\section{Black Power $(a=0.755)$ :}

- Blacks should participate in black-only organizations whenever possible.

- Blacks should always vote for black candidates when they run.

- Black people should shop in black stores whenever possible.

- Blacks should support the creation of all male public schools for black youth.

- Black children should study an African language.

- Blacks should have control over the government in mostly black communities.

- Blacks should have control over the economy in mostly black communities.

- Black people should rely on themselves and not others.

- Black people should have their own separate nation.

(strongly agree $=2$, agree $=1$, don't know/don't care $=0$, disagree $=-1$, strongly disagree $=-2$ )

\section{Black Consciousness $(a=.608)$ :}

- American society has provided black people a fair opportunity to get ahead in life. (disagree/strongly disagree $=1$, agree/strongly agree $=0$ )

- American society just hasn't dealt fairly with black people. (agree/strongly agree $=1$, disagree/strongly disagree $=0$ )

- There is still so much discrimination that special programs to help blacks and minorities are needed. (agree $=1$, disagree/don't know $=0$ )

- American society is fair to everyone $=1$, American society is unfair to black people $=0$, don't know $=0$.

- America's big corporations are unfair to the black community $=1$, America's big corporations are a powerful source of economic growth that benefits the black community $=0$, don't know $=0$.

- The American legal system is unfair to blacks $=1$, Generally, the American legal system treats all groups fairly $=0$, don't know $=0$.

- Do you think blacks have achieved racial inequality $(0)$, will soon achieve racial equality $(0)$, will not achieve racial equality in your lifetime (1), will never achieve racial equality (1)? 
Copyright of Social Forces is the property of University of North Carolina Press and its content may not be copied or emailed to multiple sites or posted to a listserv without the copyright holder's express written permission. However, users may print, download, or email articles for individual use. 